Abstracta Iranica Iranica

Revue bibliographique pour le domaine irano-aryen

Volume 24 | 2003

Comptes rendus des publications de 2001

\title{
Ouzbékistan. Grandes voix du passé (1940-1965). Paris, OCORA, 1999.
}

\section{Rédaction}

\section{(2) OpenEdition}

10 Journals

\section{Édition électronique}

URL : http://journals.openedition.org/abstractairanica/35008

DOI : 10.4000/abstractairanica.35008

ISSN : 1961-960X

Éditeur :

CNRS (UMR 7528 Mondes iraniens et indiens), Éditions de l'IFRI

\section{Édition imprimée}

Date de publication : 15 mai 2003

ISSN : 0240-8910

Référence électronique

Rédaction, «Ouzbékistan. Grandes voix du passé (1940-1965). Paris, OCORA, 1999. », Abstracta Iranica [En ligne], Volume 24 | 2003, document 372, mis en ligne le 05 janvier 2010, consulté le 25 septembre 2020. URL : http://journals.openedition.org/abstractairanica/35008; DOI : https://doi.org/10.4000/ abstractairanica.35008

Ce document a été généré automatiquement le 25 septembre 2020.

Tous droits réservés 


\section{Ouzbékistan. Grandes voix du passé (1940-1965). Paris, OCORA, 1999.}

\section{Rédaction}

Ce CD accompagné d'un livret contenant beaucoup d'informations inédites sur la musique ouzbek-tadjik, réunit des documents d'archives d'une qualité technique standard malgré leur âge. Les meilleurs chanteurs de cette époque y trouvent leur place. Le document le plus remarquable, placé en première position, est peut-être celui des frères Sobhanov, soufis dépositaires de la tradition Yasavi de Turkestan. Quelquesuns de leurs hymnes religieux avaient été enregistrés officiellement par la Radio Nationale Ouzbek dans les années 1960.

\section{INDEX}

Thèmes : 17.1.Musique

\section{AUTEURS}

\section{RÉDACTION}

Directeur de la revue et secrétariats (Paris et Téhéran) 